\title{
Yaşlanma ve alglerin anti-gerontolojik etkileri
}

\section{Aging and anti-gerontological effects of algae}

\author{
Şükran Çakır Arıca (D) \\ İskenderun Teknik Üniversitesi, Deniz Bilimleri ve Teknolojisi Fakültesi, İskenderun, Türkiye \\ sukran.cakir@iste.edu.tr
}

How to cite this paper:

Çakır Arıca, Ş. (2017). Aging and anti-gerontological effects of algae. Ege Journal of Fisheries and Aquatic Sciences, 34(4):469-474. doi: 10.12714/egejfas.2017.34.4.16

\begin{abstract}
Öz: Günümüzde yeni kentsel yaşam, çalışma koşulları ve antropojenik faaliyetlerde kullanılmakta olan kimyasallar ekolojik kirliliği beraberinde getirmiştir. Kimyasalların canlılarda metabolizma ile ilgili, sitotoksik ve mutajenik hasarlar yaptığı bilinmektedir. Kimyasalların mutajenik ve karsinojenik aktiviteleri arasında ilişki vardır. Ülkemizde en sık ölüm sebebi olan kalp-damar hastalıkları ve kanser rahatsızlıkları insanların genetik ömrünü tamamlamalarına engel oluşturmaktadır. Yaşlanma, vücut fonksiyonlarında geri dönüşümsüz ve ilerleyici bir azalma ve bu sırada yeniden şekillenme ile giden, doğum ile ölüm arasında yer alan kompleks yaşam sürecinin doğal bir parçası olarak tanımlanmaktadır. Gerontoloji Bilimi dünyasında canlılarda yaşlanma sürecini açıklamaya çalışan birçok teori mevcuttur. Somatik mutasyonlar teorisi, telomeraz aktivitesi teorisi, serbest radikaller teorisi, genetik yaşlanma teorisi, İmmünoloji ve endokrin teorisi, kalori kısıtlaması teorisi bunlardan bazılarıdır. Bu teoriler içinde serbest oksijen radikallerinin kronik, birikici etkisi ile yaşlanmayı açıklayan görüş, günümüzde önde gelen teorilerinden biridir. Bu teoriye göre küçük ama bütün yaşam boyunca süren antioksidan sistemdeki yetersizlikler yaşlanmaya neden olmaktadır. Serbest radikaller, tek sayıdaki (eşlenmemiş) elektron sayısına sahip atomlar veya atom gruplarııı ve hücredeki solunum sırasında oksijen bazı moleküller ile etkileşime girdiğinde oluş̧urulabilir. Oluştuktan sonra, bu oldukça reaktif radikaller, domino gibi, zincirleme reaksiyonlarla DNA gibi hücre moleküllerine zarar verebilirler. Bu hasarların tamir edilemeyip birikmesi kanser gibi hastalıklara neden olabilir ve yaşlanmayı hızlandııı. Antioksidanlar kanser, yaşlanma ve çeşitl hastalıkların ortak yolağı olan hücresel hasarın önlenmesinde yakından ilgilidir. Vücudun kendi antioksidan savunma sistemine ek olarak, serbest radikal hasarını önlemek için antioksidanlar gıdalarla birlikte alınmalıdır. Bu nedenle her geçen gün önemi artan bazı alg çeşitleri ve onlardan teknoloji ile elde edilen antioksidan bileşikler destek besini olarak ticari işletmelerce piyasaya sunulmaktadır. Bazı alglerin kıymetli antioksidanlar içerdiği bilinmektedir ve antioksidanlarca zengin bu alglerin anti-gerontolojik rolü önemli bir konudur. Diyete özellikle alglerden elde edilen antioksidanların eklenmesi ile bazı model hayvan türlerinde ömür uzunluğu ile ilgili pozitif sonuçlar alınmıştır. Bu çalışmanın amacı, alglerin zengin antioksidan içerikleri nedeniyle gelecekteki anti-gerontolojik potansiyellerine dikkat çekmektir.
\end{abstract}

\section{Anahtar kelimeler: Algler, yaşlanma, yaşlanma teorileri, gerontoloji, antioksidan}

Abstract: Today, a new urban living, chemicals that are being used in working conditions and anthropogenic activity has brought environmental pollution. It is known that chemicals cause metabolismal, cytotoxic and mutagenic damage on living things. There is a relationship between the mutagenic and carcinogenic chemicals activities. The most common cause of death, heart disease and cancer in Turkey, this situation creates obstacles to people's complete genetic life. Aging, leading to progressive and irreversible decrease in body functions and meanwhile remodeling, is defined as a natural part of the complex life cycle between birth and death. There are many theories trying to explain the aging process of living organisms in gerontology science. Somatic mutation theory, telomerase activity theory, the theory of free radicals, the theory of genetic aging, immunology and endocrine theory, calorie restriction theory are some of them. Nowadays, the view which explains the aging with chronic and cumulative effects of the free oxygen radicals is one of the leading theories. According to this theory, small but all imperfections in antioxidant system during the period of life cause aging. Free radicals are atoms or groups of atoms with an odd (unpaired) number of electrons and can be formed when oxygen interacts with certain molecules during the respiration in the cell. Once formed, these highly reactive radicals, such as dominoes, can damage cellular molecules such as DNA by chain reactions. The accumulation of these damages can lead to diseases such as cancer and accelerate aging. Antioxidants are closely related to the prevention of cellular damage, which is a common pathway to cancer, aging and various diseases. In addition to the body's own antioxidant defense system, antioxidants must also be taken with foods to prevent free radical damage. Therefore, some varieties of algae growing in importance every day and antioxidant compounds obtained from them by the technology have been offered to commercial enterprises by the market as nutritional supplements. It is known that some algae contain valuable antioxidants and the anti-gerontological role of these algae rich in antioxidants is an important issue. Some positive results were obtained on animal model species about longevity by dietary addition of antioxidants derived from the algae. The purpose of this study is to draw attention to the future anti-gerontological potentials of algae because of their rich antioxidant content.

Keywords: Algae; aging; aging theories; gerontology; antioxidant

\section{GíRiş}

Günümüzde yaşama koşullarının değişmesi, beslenme alışkanlıklarında da değişikliğe neden olmuş, bununla bağlantılı olarak insanlar doğadan ve doğal besin kaynaklarından

uzaklaşmışlardır. Bu durum kanser, kalp-damar hastalıkları ve obezite gibi sağlık sorunlarının toplumdaki görülme sıklığını artırmış, bilim insanlarını yaşlanmanın nedenleri ve alternatif 
çözümler konusunda arayışlara yönelmiş̧tir. Oksidatif stresin, birçok kardiyovasküler bozukluğun patogenezinde önemli bir bileşen olduğu, bu nedenle serbest radikallerin bu sistemin hücrelerinde neden olduğu hasarın azaltılmasında antioksidan savunmanın önemli bir role sahip olduğunu ve (Howden, 2013; Southgate, 1990; Schagen vd., 2012; Snare, vd., 2013). Bütün bu faktörlerin toplumda genetik ömrün tamamlanması önünde engel oluşturduğu ifade edilmektedir. Kitle iletişim araçları ve eğitimin yaygınlaşması ile bu konuda zamanla farkındalık oluşmaya başlamış, hızla artan nüfus ve karasal doğal besin kaynaklarının sınırlı oluşu insanlığı sucul doğal kaynaklara yöneltmiştir (El-Sheekh, 2006; Wong ve Cheung, 2000).

Günümüzde yaşa bağıı hastalıkların sıklığı ve şiddetinin, alternatif beslenme modelleri ile hücrelerde meydana gelen hasar birikiminin yavaşlatılması ile mümkün olacağı ve sağlıkı ömür süresinin uzatılabileceği ifade edilmektedir. Zengin biyolojik metabolit ve antioksidan içerikleri ile algler bu açıdan potansiyel olarak görülmektedir (Kasimala vd., 2015).

Türkiye, $8.333 \mathrm{~km}$ farklı iklim özellikleri olan sahil uzunluğuna sahip, üç tarafı denizlerle çevrili ve sucul sistemler açısından çok avantajlı özelliklere sahip bir ülke olmasına rağmen (Zeybek, 1969; Durucan ve Turna, 2011; Cirik vd., 2001), henüz sucul fauna ve florasından yeterince faydalanamamaktadır. Bu çalışmanın amacı, alglerin serbest radikalleri nötralize eden ve yaşlanma karşıtı etkisi olan zengin antioksidan içeriğine dikkat çekmek ve anti-gerontolojik potansiyelleri ile ilgili yapılan bazı çalışmaları da sunarak konu ile ilgili farkındalık sağlamaktır.

\section{Bazı yaşlanma teorileri}

Gerontoloji, yaşlanmanın ve yaşlılığın bilimi anlamına gelmektedir. Yaşlanma, her canlıda hayatın süreci içinde görülen, molekül, hücre, doku, organ ve sistemleri geri dönüşsüz olarak, yapı ve fonksiyonu yönünden olumsuz etkileyen bir olgudur. Bu olgunun hızı, genetik yapı, yaşama alışkanlıkları ve çevre ile bunlara bağlı olarak vücutta gerçekleşen biyokimyasal metabolizma ve immünolojik cevap ile yakından ilgilidir (Bishop ve Guarente, 2007). Hemen hemen bütün canlılar için evrensel bir gerçek olması, çevresel değişen faktörlere uyum ve vücut homeostasisini sağlama yeteneğinde azalma, vücut iç ve dış değişken nedenli strese cevap kapasitesinde azalma yaşlanmanın bütün canlılar için genel özelliklerindendir (Çakır, 2000; Browner, vd., 2004). Yaşlanmanın nedenlerini açıklamaya yönelik pek çok teori geliştirilmiştir (Medvedev, 1990; Guarente ve Kenyon, 2000; Karan ve Tufan, 2010). Biyolojik yaşlanmayı bir teori ile tam olarak açıklayabilmek mümkün değildir, çünkü yaşlanma çok faktörlü bir olgudur. Bu çalışmada bilimsel araştırmalarla destek kazanan, yaşlanmayı genetik yönü ile açıklayan güncel bazı teorilere yer verilmiştir.

Somatik Mutasyonlar Teorisi: Bu teoriye göre hücrede iç ve dış faktörlerin etkisi ile oluşan DNA hasarına hücresel cevap kapasitesinde yaşlanma ile bir azalma olmaktadır. DNA hasarına cevap, DNA'da meydana gelen hasar türünün tespiti, uygun tamir mekanizması ile tamiri, tamir mümkün değilse hücre siklusunun kontrolü veya apoptoz (hücrenin programlı şekilde ölümü) mekanizması ile hücrenin organizmaya zararsız hale getirilmesi aşamalarından oluşmaktadır.

Telomeraz Aktivitesi Teorisi: Hücrelerdeki kromozomların uç kısımlarında, kromozomların stabilitesinden sorumlu, telomer olarak adlandırılan tekrarlayan özgül DNA dizileri vardır. Hücrede kromozomların çekirdek membranına tutunarak belirli bir pozisyonu korumasını sağlar. Doğrusal DNA'ya sahip hücrelerde (kanser hücreleri gibi bazı istisnalar hariç), her hücre bölünmesi sonucunda bu telomer bölgeleri kendilerini tam olarak eşleyemezler ve bir miktar kısalırlar. Bu diziler kritik bir kısalığa ulaşsığında hücre bütünlüğünü koruyamaz ve yaşlanma ile ilgili mekanizmalar tetiklenir (Atlı ve Bozcuk, 2002; Flores, vd., 2005). Bu durum "Hayflick sınır" olarak adlandırılır (Hayflick, 1965; Hayflick, 1976). Kısalmış telomer yapısının, ateroskleroz, vasküler demans ve Alzheimer hastalığı (Taupin, 2010) gibi yaşlıkla ilişkili hastalıklarla bağlantılı olduğu bildirilmiştir.

Serbest Radikaller Teorisi: Yaşlanmaya serbest radikallerin neden olduğunu savunan bu teoriye göre, oksijenli solunum yapan bütün canlıların hücrelerinde bu metabolizma sonunda doğal olarak serbest radikaller oluşur. Bunlar en dış elektron zarfında bir elektron kaybetmiş ve dolayısıyla bu elektron açığını kapatabilmek için hücredeki başka atomların elektronlarını paylaşmaya çalışan atomlardır. Antioksidanlar tarafından dengelenmedikçe, bu reaktif oksijen türevleri hücrenin yapıtaşı olan hücre zarına, proteinlere, yağlara ve DNA'ya zarar veririler (Sohal, vd., 2002, Şekeroğlu ve Şekeroğlu, 2009). Bu teoriye göre, yaşla birlikte bu dengeleme yeteneği azalır, bu nedenle vücudun ürettiği antioksidan enzimlere ilaveten besinle antioksidan almanın ömür uzunluğu üzerine olumlu etkisi olabilir. Bu düşüncenin insan üzerinde deneysel kanıtlandığı çalışmalar olmamakla birlikte model hayvanlarla yapılan bazı deney sonuçları (Guarente ve Kenyon, 2000; Shimokawa ve Trindade, 2010) diyete antioksidan eklenmesinin ömür uzunluğunu pozitif etkilediğini göstermiş̧tir. Ayrıca, çevre kirliliği, sigara, herbisit ve pestisitler, bazı çözücüler, ilaçlar, zararlı güneş ışınları, bazı tıbbi tedaviler, bazı gıda bulaşanlarının da hücrelerde serbest radikal oluşumunu artırdığı bilinmektedir (Çakır Arıca ve Sarıkaya, 2005).

Genetik Yaşlanma Teorisi: Canlıların ömür uzunluğunu soy, cins ve ırka bağlı olarak, DNA şifremize dayandıran bir teoridir. Her ne kadar yaşama alışkanlıkları ve çevre koşulları yaşlanma hızını etkilese de her canlı türü için genlerde kodlanmış bir üst limitin (genetik yaş) olduğunu ifade eder. Her canlı türünün ve hücresinin kendine göre az çok belirlenmiş bir ortalama ömrünün bulunması bu teoriyi desteklemektedir (Hayflick, 1965; Hayflick, 1976). Genel olarak kadınların erkeklere göre beklenen yaşam süresinin daha uzun olması da genetik nedene dayanır.

İmmünolojik ve Endokrin Teorisi: Yaşlanma ile beraber vücudun yabancı ve kendi elemanlarını tanıma ve ayırt etme 
yeteneği azalır. Bağışıklık (immün) sistem yaşlanınca, vücudun kendi dokuları ile yabancı olan arasındaki farkı tanıma yeteneğini kaybetmeye başlar ve vücut savunması aksar. Bu teoriye göre, endokrin bezlerin hormon salgılamalarındaki düzensizlik veya yetersizlik yaşlanmayı başlatmaktadır.

Kalori Kısıtlaması: Beslenme ve yaşlanma her zaman ilişkili bulunmuştur. Örneğin, henüz mekanizması tam olarak bilinmemekle beraber, mayalardan memelilere kadar, eğer eksik ve yanlış beslenme yoksa, kalori kısıtlamasının yaşlanmayı geciktirdiği ve ömrü uzattığı deneysel verilerle genel olarak kabul görmektedir (Masoro, 2000; Smith, , vd., 2004; Shimokawa ve Trindade, 2010).

\section{Alglerin potansiyel içerikleri}

Denizlerin önemli zenginliklerinden biri olan algler, biyolojik ve ekolojik fonksiyonları ile sucul ekosistemin primer üreticisi olmaları yanında, özellikle bazı uzak doğu ülkelerinde insan beslenmesinde de önemli bir yere sahiptir. Ayrıca, hücre duvarında bulunan agar, aljinat ve karaginin gibi polisakkaritler eczacılıkta ve gıda endüstrisinde katkı maddesi olarak kullanılırken, antibakteriyal, antiviral, antikanser, antifungal gibi etkileri olan değerli kimyasal içeriklere de sahip oldukları bilinmektedir (Gökpınar vd., 2006; Kasimala vd., 2015).

Dünyada Phaeophyceae (Ochrophycea) ve Rhodophyceae sınıflarından olan 100'den fazla alg türü içerdikleri protein, karbonhidrat, vitamin ve minerallerin varlığından dolay dünyanın çeşitli yerlerinde insanlar tarafından besin kaynağı olarak kullanılmaktadır (Oğur, S. 2016). Örneğin, gıda takviyesi olarak kullanılan tatlı su mavi-yeşil alglerden Spirulina platensis'in, protein, esansiyel yağ asitleri, antioksidan karotenoidler, B vitamini kompleksi, E vitamini, bakır, manganez, magnezyum, demir, selenyum ve çinko gibi mineral içeriği açısından zengin bir kimyasal koruyucu olduğu ve gıda takviyesi olarak alındığında damar sertliği, diyabet, hidroksil radikalleri yakalayarak kansere karşı koruyucu etki gösterdiği gözlenmiştir (Ovando, vd., 2016). Ayrıca, Padina pavonia'nın antiproliferetif ve antikarsinojen etkisi araştırımış ve kolon kanserinde pozitif etkisinin olabileceği bildirilmiştir. Başka bir çalışmalarda, U. lactuca'nın protein ve vitamin içeriği açısından zengin özellikte olduğu, uzak doğu ülkelerinde gıda ve gübre amacıyla kullanıldığı (Durucan ve Turna 2011; Chu, vd., 2010; Huangfu, vd., 2013) bildirilmiştir. Son yıllarda araştırmacılar alglerde bulunan antioksidan bileşikler ve bunlardan porphyran ve shinorinenin yaşlanma karşıtı etkisine dikkat çekmektedir (Munir, 2013; Cornish ve Garbary, 2010). Ayrıca Olasehinde ve arkadaşları (2017) patogenezi, oksidatif stres, kolinerjik işlev bozukluğu, nöronal hasar, protein yanlış katlanması ve agregasyonu ile ilişkili kompleks mekanizmaları içeren yaşlanma ile ilişkili Alzheimer hastalığının tedavisinde, bazı mikroalgal biyoaktif bileşiklerin ve ekstraktların beyinde nöronal hasarın yanı sıra hafıza bozukluğunu önleyebileceğine dair artan kanıtlardan bahsetmesi ümit vericidir.

Doğal antioksidanlar olan flavonoidler, fenolik bileşikler, tanninler ve terpenlerin hücredeki kararsız yapıdaki serbest radikalleri nötralize ederek hücreleri korur. Bu nedenle, son zamanlarda doğal antioksidan kaynakları olarak bilinen bazı alglerin hücre koruyucu ve onarıcı özelliklerinden dolayı biyoteknolojik üretimleri yapılmaktadır. Örneğin, özel tekniklerle kültüre alınan bazı alglerde yoğun beta-karoten, astaksantin, zeaksantin, lutein gibi kuvvetli antioksidan özelliklere sahip pigment maddelerinin miktarı artırılabilmiştir. Son yıllarda model hayvanlar ile yapılan ömür uzunluğu çalışmalarında alglerden bazı olumlu sonuçlar alınmıştır (Tablo 1). Algler, zengin antioksidan içeriklerinin fark edilmesi ile son yıllarda önem kazanmışlardır (Gökpınar, vd. 2006; Cornish ve Garbary, 2010). Çünkü doğal antioksidanların dejeneratif bazı hastalıklarda hücre koruyucu ve tedavi edici etkisinin olduğu bildirilmektedir. Kemoterapinin yan etkilerinin tolare edilmesinde de antioksidan içeren gıdalar öne çıkmaktadır. Bu sonuçlar, insan ömrünün uzatılması ve kaliteli yaşıılık kriterlerinin sağlanması açısından alglerin gelecekte bir potansiyel olabileceği fikrini desteklemektedir.

Tablo 1. Bazı alg türlerinin anti-gerontolojik aktiviteleri ve bunların test edilen bileşikleri üzerine daha önce rapor edilen bazı araştırma sonuçları Table 1. Some previously reported research results on anti-gerontological activities and their tested compounds of some algae species

\section{Bazı alg türlerinin anti-gerontolojik aktiviteleri ve bunların test edilen bileşikleri ile ilgili Kaynaklar} rapor edilen araştırma sonuçları

Porphyra haitanesis (Rhodephyta). Porphyra haitanesis'in (Rhodephyta) sülfatlanmış polisakarit fraksiyonunun (F2), antioksidan enzim aktivitesi, lipit peroksidasyonu ve toplam antioksidan kapasitesinde yaşlıı̆̆a bağı değişiklikler farede in vivo olarak farklı dokularda incelendi. F2'nin, toplam antioksidan kapasitesindeki azalmayı ve antioksidan enzimlerin faaliyetlerini telafi etmekte ve böylece lipid peroksidasyon riskini azaltmakta etkili olduğu rapor edildi.

Makroalglerden (Endarachne binghamiae, Schizymenia dubyi, Ecklonia cava and Sargassum, Silquastrum, Sargassum polycystum) türetilen bileşiklerin dermatolojide potansiyel terapötik maddeler olduğu, elde edilen bazı özütlerin cilde renk veren melanin pigmenti ile ilgili tirozinaz inhibe edici aktivitesi ile cildi foto hasarların yaşlanma etkisinden ve deri kanseri melanomadan koruduğuna dair bulgulara yer verildi. Ayrıca, Sargassum muticum'dan izole edilen tetrapreniltolukuinol kroman meroterpenoid ve Ecklonia cava'dan izole edilen Eckstolonolun fotoyaşlanmaya karşı etkilerine yer verildi.
Zhang, Q., vd., 2003

Wang H.D. vd.,2017; Cha, S. H., vd., 2011 Chan, Y. Y., vd., 2011; Balboa, E. M., vd., 2015 Jang, J., vd., 2012 
Porphyra haitanensis'den elde edilen porfirinlerin diyetle alınmasının, erkek ve dişi Drosophila melanogaster'de ömrü uzattığı ifade edilmiştir.

Lipidlerin oksidatif bozunmasının, insanlarda ateroskleroz, yaşlanma ve karsinogenezide öneml rol oynadığı, gıdaların raf ömrünü uzatmada kullanılan sentetik antioksidanlar yerine alglerden elde edilen doğal antioksidanların sağlık risklerini azaltarak ömrü uzatacağı ifade edilmiştir.

Asya'da en çok yenilen bir kırmızı deniz yosunu olan Porphyra tenera'dan elde edilen uçucu yağın (PTVO) ömür uzatan antioksidan potansiyeli in vitro biyokimyasal deneyler ile değerlendirildi.

Güneşin, canlıları UV-A ve UV-B gibi zararlı radyasyona maruz bıraktığı ve alglerin UV'nin zararını gidermek için MAA'lar, scytonemin, karotenoidler ve diğer bazı bileşikler gibi bir dizi fotokoruyucu bileşiği sentezleyerek veya biriktirerek toksisiteden kaçınma, onarım ve koruma gibi bazı mekanizmalar geliştirdiği belirtilerek, bu fotoprotektif bileşiklerin dermatolojik yaşlanmayı önleyici özelliklerine dikkat çekildi.

SIRT gen ailesinin kodladığı proteinlerin, histonların deasetilasyonu kromatinin yoğunlaşmas (heterokromatin) ile gen ifadesinin baskılanmasında rol aldığı bilinmektedir.

Kanser, obezite ve insüline dirençli diyabet de dahil olmak üzere yaşla ilişkili hastalıkların ve metabolik sendroma bağlı bozuklukların önlenmesinde kullanılabilecek potansiyel adaylar olarak yeni SIRT6 modülatörleri için kahverengi yosun türlerinin tarandığı ve SIRT6 modüle edic aktiviteye karşı test edilen beş çeşit kahverengi yosundan F. distichus'un aktif maddesi fukoidanın SIRT6 deasetilasyon aktivitesini doz bağımlı bir şekilde artırdığı ifade edildi. SIRT6 eksikliğinin farelerin yaşamını kısalttığı, aşııı ekspresyonunun ise erkek farelerin ömrünü uzattığı ve diyetle indüklenen obeziteyi önlediği ifade edildi.

Hücre kültürleri ile yapılan çalışmalarda, ticari olarak da üretilen ve tek hücreli alg olan Haematococcus pluvialis'den elde edilen Astaxanthin'in Hücre mitokondrisini endojen oksijen radikallerine karşı koruduğu ve onların enerji üretim verimliliğini geliştirdiği, insanda yaşa bağlı bazı fonksiyonların azalmasında da önleyici olabileceği ifade edildi.

Üç yeşil mikro algin (Dunaliella tertiolecta, Tetraselmis Suecica ve Nannochloropsis sp) yağ ekstraksiyonundan sonra kalan kalıntısı analiz edilmiş ve Antioksidan ve anti-aging kapasitesi ekonomik açısından endüstriyel önemde bulunmuştur. Mikroalgden biyoyakıt üretimi ve atığın nutrasötik ve nutrikosmetik alanda endüstriyel kullanımının sürdürülebilirliği ve ekonomik katkısına dikkat çekilmiştir.

Algal biyokütleden ekstrakte edilen fonksiyonel bileşenlerin diyet ve sağlık açısından yaygın olarak kullanıldığı belirtilen bu derlemede, yosunlardaki insan derisi tedavilerine ilişkin aktif bileşiklerden bahsedilip, anti enfeksiyon, anti-aging, cilt-beyazlatma ve cilt tümörü tedavileri için yüksek potansiyel oldukları ile ilgili araştırma sonuçlarına yer verilmiştir.
Zhao, T. vd., 2008

Jin, C. vd., 2016

Patra, J. K. vd., 2017

Rastogi, R.P., 2010

Kanfi, Y. vd., 2012.

Rahnasto-Rilla, M. K. vd., 2017

Kidd, 2011

Norzagaray-Valenzuela, C. D. vd., 2017

Wang, D. vd., 2017

\section{TARTIŞMA VE SONUÇ}

Algler günümüzde zengin içerikleri nedeniyle gıda, ziraat, eczacılık, tıp, biyoteknoloji ve hatta biyo-yakıt olarak enerji gibi birçok endüstriyel alanda gelecek vadeden potansiyel olarak dikkat çekmektedir. Yaşadığımız çevrenin sanayi, tarımsal faaliyetler, antropojenik etkiler gibi faktörlerle kirlenmesi soluduğumuz havayı, temas ettiğimiz eşyaları ve hatta besinlerimizi kirletmiştir. Bu durum, başta DNA olmak üzere, hücre biyomolekülleri için yıkıcı etkisi olan serbest radikallerin hücrelerde oluşumu ve genotoksik etkisini artırmaktadır (Sarıkaya ve Çakır, 2005; Sarıkaya vd, 2006).

Bütün canlılar için evrensel bir gerçek olan yaşlanma çok faktörlü bir olgudur. Çevresel değişen faktörlere uyum ve vücut homeostasisini sağlama yeteneğinde azalma, vücut iç ve dış değişken nedenli strese cevap kapasitesinde azalma genel özelliklerindendir. İyi yaşama beslenme ile bu olgunun önlenemese de yavaşlatılıası ve kaliteli bir yaşlılığın mümkün olduğu ve ölüm nedenlerinin başında gelen kanser ve kalpdamar hastalıkları gibi metabolizma ile ilgili hastalıkların azaltılabileceği ve hatta yaşlanmayanın geciktirebileceği ifade edilmektedir. Bu bağlamda, bazı alglerin hücredeki serbest radikalleri etkisiz hale getiren antioksidan özellikteki flavonoid ve karotenoidler gibi besin öğelerince zengin oluşu, onları günümüzde potansiyel canlılar ve etken madde kaynağı olarak ön plana çıkarmıştır (Bhuvaneswari, vd., 2013; Burçak ve Andican, 2004; Chandini vd., 2008).

Bu nedenle, dünyanın bazı ülkelerinde yıllardır sağlıklı beslenmenin vazgeçilmez bir unsuru olan ve antioksidan içeriği 
zengin alglerin (Drum, 2013), insan beslenmesinde gelecek vadeden potansiyeli göz ardı edilemez. Üç tarafı denizlerle çevrili olan Türkiye'nin sularında potansiyel olarak var olan ve

\section{KAYNAKÇA}

Atlı, K. \& Bozcuk, A.N. (2002). Telomer ve hücresel yaşlanma. Geriatri, 5(3):111-114.

Balboa, E.M., Li, Y.X., Ahn, B.N., Eom, S.H., Domínguez, H., Jiménez, C. \& Rodríguez, J. (2015). Photodamage attenuation effect by a tetraprenyltoluquinol chromane meroterpenoid isolated from Sargassum muticum. Journal of Photochemistry and Photobiology B: Biology, 14851 58. doi: 10.1016/j.jphotobiol.2015.03.026

Bhuvaneswari, S., Murugesan, S., Subha, T.S., Dhamotharan, R. \& Shettu, N. (2013). Journal of Chemical and Pharmaceutical Research, 5(3):82-85.

Bishop, N.A. \& Guarente, L. (2007). Genetic links between diet and lifespan: shared mechanisms from yeast to humans. Nature Reviews Genetics, 8(11):835-844. doi: $10.1038 / n r g 2188$

Browner, W.S., Kahn, A.J., Ziv, E., Reiner, A.P., Oshima, J., Cawthon, R.M., \& Cummings, S.R. (2004). The genetics of human longevity. The American Journal of Medicine, 117(11):851-860. doi: 10.1016/j.amjmed.2004.06.033

Burçak, G. \& Andican, G. (2004). Oksidatif DNA hasarı ve yaşlanma. Cerrahpaşa Tıp Dergisi, 35(4):159-169.

Cao, J., Wang, J., Wang, S. \& Xu, X. (2016). Porphyra species: a mini-review of its pharmacological and nutritional properties. Journal of Medicinal Food, 19(2):111-119. doi: 10.1089/jmf.2015.3426

CHA, S.H., KO, S.C., Kim, D., \& JEON, Y.J. (2011). Screening of marine algae for potential tyrosinase inhibitor: those inhibitors reduced tyrosinase activity and melanin synthesis in zebrafish. The Journal of Dermatology, 38(4):354-363. 10.1111/j.1346-8138.2010.00983.X

Chan, Y.Y., Kim, K.H., \& Cheah, S.H. (2011). Inhibitory effects of Sargassum polycystum on tyrosinase activity and melanin formation in B16F10 murine melanoma cells. Journal of Ethnopharmacology, 137(3):1183-1188. doi: 10.1016/j.jep.2011.07.050

Chandini, S.K., Ganesan, P. \& Bhaskar, N. (2008). In vitro antioxidant activities of three selected brown seaweeds of India. Food Chemistry, 107(2):707713. doi: 10.1016/j.foodchem.2007.08.081

Chu, W.L., Lim, Y.W., Radhakrishnan, A.K., \& Lim, P.E. (2010). Protective effect of aqueous extract from Spirulina platensis against cell death induced by free radicals. BMC Complementary and Alternative Medicine, 10(1):53. doi: 10.1186/1472-6882-10-53

Cirik, Ş., Akçalı, B. \& Bilecik, N. (2001). Gökova Körfezi (Ege Denizi) deniz bitkileri. Piri Reis Bilim Serisi No.4, DEÜ-DBTE, Yayın No.09.8888.6000/DK.01.001.260, İzmir, $95 \mathrm{~s}$.

Çakır Arıca, Ş. \& Sarıkaya, R., (2005). Genotoxicity testing of some organophosphate insecticides in the Drosophila wing spot test. Food and Chemical Toxicology, 43(3):443-450. doi:10.1016/j.fct.2004.11.010

Çakır, S.. (2000). Genetics and Some Aging-Related Mechanisms. Turkish Journal of Zoology, 24(2):183-190.

Cornish M. L. ve Garbary, D. J. 2010. Antioxidant from macroalgae: Potentia applications in human health and nutrition. Algae 25(4):155-171 doi: 10.4490/algae.2010.25.4.155

Drum, R., 2013. Sea Vegetables for Food and Medicine, Well Being Journal, 3 12

Durucan, F. \& Turna, İ.I. (2011). Antalya Batı Kıyılarının (Antalya-Kalkan) Makrobentik Deniz Algleri. Süleyman Demirel Üniversitesi Fen Dergisi, 6(2):91-98

El-Sheekh, M.M., Osman, M.E., Dyab, M.A. \& Amer, M.S. (2006). Production and characterization of antimicrobial active substance from the cyanobacterium Nostoc muscorum. Environmental Toxicology and Pharmacology, 21(1):42-50. doi: 10.1016/j.etap.2005.06.006 değerlendirilmeyen bu organizmalar doğal ilaç hammaddeleri ve alternatif besin katkları olarak ekonomiye kazandırılabilir ve sağlık sektörü için gelecekte güçlü bir alternatif olabilir.

Flores, I., Cayuela, M.L., \& Blasco, M.A. (2005). Effects of telomerase and telomere length on epidermal stem cell behavior. Science, 309(5738):1253-1256. doi: 10.1126/science.1115025

Gökpınar, Ş., Koray, T., Akçiçek, E., Göksan, T., \& Durmaz, Y. (2006). Algal Antioksidanlar. Ege Journal of Fisheries and Aquatic Sciences, 23(11):85-89.

Guarente, L., \& Kenyon, C. (2000). Genetic pathways that regulate ageing in model organisms. Nature, 408(6809): 255-262. doi: 10.1038/35041700

Hayflick, L. (1965). The limited in vitro lifetime of human diploid cell strains. Experimental Cell Research, 37(3):614-636. doi: 10.1016/0014-4827(65)90211-9

Hayflick, L. (1976). The cell biology of human aging. New England Journal of Medicine, 295(23):1302-1308. doi: 10.1056/NEJM197612022952308

Howden, R., 2013. Nrf2 and Cardiovascular Defense Hindawi Publishing Corporation Oxidative Medicine and Cellular Longevity Volume 2013, Article ID 104308, 10 pages. doi:10.1155/2013/104308

Huangfu, J., Liu, J., Sun, Z., Wang, M., Jiang, Y., Chen, Z.Y., \& Chen, F. (2013) Antiaging effects of astaxanthin-rich alga Haematococcus pluvialis on fruit flies under oxidative stress. Journal of Agricultural and Food Chemistry, 61(32):7800-7804. doi: 10.1021/jf402224w

Jang, J., Ye, B.R., Heo, S.J., Oh, C., Kang, D.H., Kim, J.H., Affan, A., Yoon K.T., Choi, Y.U., Park, S.C., Han, S., Qian, Z.J., Jung, W.K. \& Choi, II-W. (2012). Photo-oxidative stress by ultraviolet-B radiation and antioxidative defense of eckstolonol in human keratinocytes. Environmental Toxicology and Pharmacology, 34(2):926-934. doi: 10.1016/j.etap.2012.08.003

Kanfi, Y., Naiman, S., Amir, G., Peshti, V., Zinman, G., Nahum, L., Joseph, Z.B \& Cohen, H.Y. (2012). The sirtuin SIRT6 regulates lifespan in male mice. Nature, 483(7388):218-221. doi: 10.1038/nature10815

Karan, M. A., \& Tufan, F. (2010). Yaşlanma mekanizmaları. Ege Tıp Dergisi, 49(10):11-17

Kasimala, M. B., Mebrahtu, L., Magoha, P. P., Asgedom, G., \& Kasimala, M. B. (2015). A review on biochemical composition and nutritional aspects of seaweeds. Caribbean Journal of Science and Technology, 3:789-97.

Kidd, P., 2011.Astaxanthin, Cell Membrane Nutrient with Diverse Clinical Benefits and Anti- Aging Potential. Alternative Medicine Review Volume 16, Number 4

Masoro, E. J. (2000). Caloric restriction and aging: an update. Experimenta Gerontology, 35(3):299-305. doi: 10.1016/S0531-5565(00)00084-X

Medvedev, Z. A. (1990). An attempt at a rational classification of theories of ageing. Biological Reviews, 65(3):375-398 doi: 10.1111/j.1469-185X.1990.tb01428.x

Munir, N., Sharif, N., Naz, Shagufta, Marzoor, F. (2013). Algae: A potent antioxidant source. Sky Journal of Microbiology Research, 1(3):22-31, April, 2013 http://www.skyjournals.org/SJMR

Norzagaray-Valenzuela, C.D., Valdez-Ortiz, A. Shelton, L.M, Jiménez-Edeza M., Rivera-López, J., Valdez-Flores AGermán-Báez, L.J. (2017). Residual biomasses and protein hydrolysates of three green microalgae species exhibit antioxidant and anti-aging activity. J Appl Phycol, 29:189-198. doi:10.1007/s10811-016-0938-9

Oğur, S. (2016). Kurutulmuş alglerin besin değeri ve gıda olarak kullanımı. Ege Journal of Fisheries and Aquatic Sciences, 33(1):67-79. doi: 10.12714/egejfas.2016.33.1.10

Olasehinde, T.A., Olaniran, A.O., Okoh, A.I. 2017. Therapeutic Potentials of Microalgae in the Treatment of Alzheimer's Disease. Molecules 2(3):480. doi:10.3390/molecules22030480

Ovando, C.A., de Carvalho, J.C., Pereira, G.V.D.M., Jacques, P., Soccol, V.T., \& Soccol, C.R. (2016). Functional properties and health benefits of 
bioactive peptides derived from Spirulina: A review. Food Reviews International, 1-18.

Patra, J.K., Lee, S.W., Kwon, Y.S., Park, J.G., \& Baek, K.H. (2017). Chemical characterization and antioxidant potential of volatile oil from an edible seaweed Porphyra tenera (Kjellman, 1897). Chemistry Central Journal 11(1):34. doi: 10.1186/s13065-017-0259-3

Rahnasto-Rilla, M.K., McLoughlin, P., Kulikowicz, T., Doyle, M., Bohr, V.A., Lahtela-Kakkonen, M., Ferruci, L., Hayes, M. \& Moaddel, R. (2017). The Identification of a SIRT6 Activator from Brown Algae Fucus distichus. Marine Drugs, 15(6):190. doi: 10.3390/md15060190

Rastogi, R.P. (2010). Photoprotective compounds from marine organisms. Journal of Industrial Microbiology \& Biotechnology, 37(6):537-558. doi: 10.1007/s10295-010-0718-5

Sarıkaya, R. \& Çakır, Ş. (2005). Genotoxicity testing of four food preservatives and their combinations in the Drosophila wing spot test. Environmental Toxicology and Pharmacology, 20(3):424-430. doi: 10.1016/j.etap.2005.05.002

Sarıkaya, R., Cakır, S. \& Solak, K. (2006). Effects of food preservatives on the longevity of Drosophila melanogaster (mwhxflr). Kastamonu Education Journal, 14:173-184.

Schagen, S.K., Zampeli, V.A., Makrantonaki, E. \& Zouboulis, C.C. (2012) Discovering the link between nutrition and skin aging. Dermatoendocrinology, 4(3):298-307. doi: 10.4161/derm.22876

Shimokawa, I. \& Trindade, L.S. (2010). Dietary restriction and aging in rodents: a current view on its molecular mechanisms. Aging and Disease, 1(2):89.

Smith, J.V., Heilbronn, L.K. \& Ravussin, E. (2004). Energy restriction and aging Current Opinion in Clinical Nutrition \& Metabolic Care, 7(6):615-622. doi: 10.1097/00075197-200411000-00005

Snare, D.J., Fields, A.M., Snell, T.W. \& Kubanek, J. (2013). Lifespan extension of rotifers by treatment with red algal extracts. Experimental Gerontology, 48(12):1420-1427. doi: 10.1016/j.exger.2013.09.007
Sohal, R.S., Mockett, R.J. \& Orr, W.C. (2002). Mechanisms of aging: an appraisal of the oxidative stress hypothesis 1, 2. Free Radical Biology and Medicine, 33(5):575-586. doi: 10.1016/S0891-5849(02)00886-9

Southgate, D.A.T. (1990). Dietary fiber and health. Dietary Fibre: Chemical and Biological Aspects, (Southgate, D.A.T., Waldron, K., johnson, I.T. and Fenwick, G.R., eds), pp. 282-284, The Royal Society of Chemistry, Cambridge, UK.

Şekeroğlu, Z.A. \& Şekeroğlu, V. (2009). Oksidatif mitokondrial hasar ve yaşlanmadaki önemi. Türk Bilimsel Derlemeler Dergisi, 2(2):69-74.

Taupin, P. (2010). A dual activity of ROS and oxidative stress on adult neurogenesis and Alzheimer's disease. Central Nervous System Agents in Medicinal Chemistry (Formerly Current Medicinal Chemistry-Central Nervous System Agents), 10(1):16-21.

Wang, H.M.D., Li, X.C., Lee, D.J. \& Chang, J.S. (2017). Potential biomedical applications of marine algae. Bioresource Technology, 244(2):1407-1415. doi: 10.1016/j.biortech.2017.05.198

Wong, K.H. \& Cheung, P. C. (2000). Nutritional evaluation of some subtropical red and green seaweeds: Part I-proximate composition, amino acid profiles and some physico-chemical properties. Food Chemistry, 71(4):475-482. doi: 10.1016/S0308-8146(00)00175-8

Zeybek, N. (1969). Türkiye'nin Akdeniz Algleri. Bodrum-Finike Körfezi sahil boyu, 2. Ege Denizi-Edremit Saros Körfezi-Sile. TBAG-124 nolu proje.

Zhang, Q., Li, N., Zhou, G., Lu, X., Xu, Z. \& Li, Z. (2003). In vivo antioxidant activity of polysaccharide fraction from Porphyra haitanesis (Rhodephyta) in aging mice. Pharmacological Research, 48(2):151-155. doi: 10.1016/S1043-6618(03)00103-8

Zhao, T., Zhang, Q., Qi, H., Liu, X. \& Li, Z. (2008). Extension of life span and improvement of vitality of Drosophila melanogaster by long-term supplementation with different molecular weight polysaccharides from Porphyra haitanensis. Pharmacological Research, 57(1):67-72. doi: 10.1016/j.phrs.2007.12.001 